Tersedia Online di http://journal.unismuh.ac.id/index.php/otoritas

Otoritas : Jurnal Ilmu Pemerintahan, 7 (1), April 2017, 37-45

\title{
Pengaruh Komunikasi Horizontal Terhadap Kinerja Pegawai Pada Badan Pemberdayaan Masyarakat Kampung di Kabupaten Jayawijaya
}

\author{
Siti Khikmatul Rizqi*), Raodah \\ Program Studi Ilmu Pemerintahan, STISIP Amal Ilmiah Yapis Wamena, Jalan Trikora, Hom-Hom, \\ Wamena, Kab. Jayawijaya 99511, Papua, Indonesia
}

Diterima: 8 Februari 2017; Disetujui: 27 Maret 2017; Dipublikasikan: 14 April 2017

\begin{abstract}
This article discusses the effect of Horizontal Communication on Employee Performance at the Office of Community Empowerment Agency (BPMK) Jayawijaya Regency. This study consists of two variables, namely as a horizontal free communication variable with research indicators: coordination, problem solving and information exchange. While the dependent variable of employee performance with research indicator: result, benefit and impact. In the sampling of the authors using saturated samples in which the entire population is used as a sample of 27 employees. And data analysis technique that writer use is statistical data analysis with type of associative research and data processed by using simple regression model. The results showed horizontal communication is very strong and direct 0.795 (significant) with employee performance at 95\% confidence level. Horizontal communication contributes to employee performance of $32.0 \%$.
\end{abstract}

Keywords: Civil Servant; Horizontal Communication; Performance

\begin{abstract}
Abstrak
Artikel ini membahas tentang pengaruh Komunikasi Horizontal Terhadap Kinerja Pegawai pada Kantor Badan Pemberdayaan Masyarakat Kampung (BPMK) Kabupaten Jayawijaya. Penelitian ini terdiri dari dua variable yaitu sebagai variabel bebas komunikasi horizontal dengan indikator penelitian: koordinasi, pemecahan masalah dan pertukaran informasi. Sementara variabel terikat kinerja pegawai dengan indikator penelitian : hasil, manfaat dan dampak. Dalam penarikan sampel penulis menggunakan sampel jenuh dimana seluruh populasi dijadikan sampel yaitu berjumlah 27 pegawai. Dan teknik analisa data yang penulis gunakan adalah analisa data statistik dengan jenis penelitian asosiatif dan data diolah menggunakan model regresi sederhana. Hasil penelitian menunjukkan komunikasi horizontal berhubungan sangat kuat dan searah sebesar 0,795 (signifikan) dengan kinerja pegawai pada taraf kepercayaan 95\%. Komunikasi horizontal memberikan kontribusi terhadap kinerja pegawai sebesar 32,0\%.
\end{abstract}

Kata kunci: Aparatur Sipil Negara: Komunikasi Horizontal; Kinerja

Cara Penulisan Sitasi: Rizki, K. H., \& Raodah, R. (2017). Pengaruh Komunikasi Horizontal Terhadap Kinerja Pegawai Pada Badan Pemberdayaan Masyarakat Kampung di Kabupaten Jayawijaya. Otoritas : Jurnal Ilmu Pemerintahan, 7(1), 37-45.

${ }^{*}$ Penulis Korespondensi.

E-Mail : sitikhikmatulrizqi@yahoo.com

Copyright (C) 2017, Otoritas : Jurnal Ilmu Pemerintahan, p-ISSN: 2088-3706, e-ISSN: 2502-9320 
Tersedia Online di http://journal.unismuh.ac.id/index.php/otoritas

Otoritas : Jurnal Ilmu Pemerintahan, 7 (1), April 2017, 38

\section{Pendahuluan}

Keberhasilan dalam pelaksanaan serta prestasi otonomi daerah sangat ditentukan oleh kesiapan dan kemampuan daerah itu sendiri dalam mengelola dan memberdayakan seluruh potensi dan sumber daya yang tersedia. Oleh karena itu diperlukan aparat birokrasi yang semakin kompeten dan bertanggung jawab. Pelaksanaan otonomi daerah adalah terselenggaranya pemerintahan yang good governance, yakni menghasilkan birokrasi yang handal dan profesional, efisien, produktif serta memberikan pelayanan prima kepada masyarakat sehingga masyarakat dan pemerintah menjadi sinkron yaitu saling bersentuhan, menunjang dan melengkapi dalam satu kesatuan langkah menuju tercapainya tujuan Pembangunan Nasional (Sedarmayanti,1997).

Sebagai Aparatur Sipil Negara, Pegawai dituntut dapat melaksanakan dan menyelesaikan pekerjaan sesuai tugas pokok dan fungsinya dengan baik serta mempunyai rasa tanggung jawab yang tinggi dengan memperhatikan peraturanperaturan yang telah ditetapkan pemerintah. Dengan adanya kemampuan, motivasi dan semangat yang baik, akan berimplikasi pada semakin meningkatnya kinerja mereka. Dengan berbekal pengetahuan dan kemampuan serta potensipotensi yang ada, para pegawai dituntut agar memberikan kontribusi pada berbagai pekerjaan yang ada sesuai peran masing-masing. Masing-masing pegawai hendaknya diberikan tanggung jawab, kewenangan yang jelas dan mempunyai uraian pekerjaan (job description) serta terlibat di dalam berbagai kegiatan. Di samping itu tugas-tugas dibagi habis kepada pegawai (staf) yang ada secara adil dan merata sesuai dengan potensi yang dimilikinya.

Hadirnya struktur kelembagaan pemerintah yang selama ini belum memberikan indikasi terciptanya kondisi kondusif dalam mengantisipasi era Otonomi
Daerah dengan dinamika perkembangan yang begitu cepat. Aparat pada level lapangan yang bersifat operasional sebagai ujung tombak di lapangan belum banyak tersentuh. Aparat lebih banyak diarahkan untuk mengisi dan memenuhi aspek struktural (eselonisasi) dan lebih bersifat manajer dan prestise bagi seorang aparat yang mengakibatkan aspek pelayanan sangat sulit tercapai dan bahkan telah membentuk budaya ingin dilayani di kalangan birokrasi.Pencapaian pemerintahan yang bersih tentunya didukung oleh struktur organisasi yang efisien dan efektif yang terbentuk dalam sebuah team work yang tangguh dan solid dalam pelaksanaan tugas-tugas kemasyarakatan, pembangunan dan pemerintahan dalam rangka Otonomi Daerah.

Badan Pemberdayaan Masyarakat Kampung Kabupaten Jayawijaya mempunyai tugas mengkoordinasikan pelaksanaan program pemberdayaan masyarakat kampung. Dengan banyaknya tugas dan fungsi Badan Pemberdayaan Masyarakat Kampung Kabupaten Jayawijaya maka dibutuhkan kualitas SDM dalam hal ini adalah pegawai yang mampu mengemban tugas secara prima. Salah satu faktor yang seringkali menjadi kendala adalah kurangnya komunikasi yang efektif, sehingga pekerjaan menjadi lebih lamban dan tidak lancar. Komunikasi dalam organisasi memiliki peranan penting, karena memberikan dampak positif terhadap semangat dan mental kerja karyawan, sehingga pada akhirnya dapat mendukung karyawan dalam mencapai prestasi kerja secaramemuaskan (Sriwidodo \& Haryanto, 2010).

Hasil pengamatan penulis di lapangan menunjukkan bahwa Masalah yang seringkali terjadi pada Badan Pemberdayaan Masyarakat Kampung Kabupaten Jayawijaya yaitu apabila ada program atau proyek yang dilaksanakan kurang koordinasi antar bidang-bidang yang ada, kurang adanya kerjasama yang 
Tersedia Online di http://journal.unismuh.ac.id/index.php/otoritas

Otoritas : Jurnal Ilmu Pemerintahan, 7 (1), April 2017, 39

baik antar pegawai dan pegawai tidak dilibatkan dalam kegiatan atau program tersebut, akhirnya menimbulkan kesalahpahaman di antara pegawai dan pegawai kurang bekerja atau berkinerja. Dan bila dilihat dari hubungan antar staf atau pegawai kurang kondusif. Hal ini disebabkan karena kurang adanya keterbukaan, dan terjadi saling curiga mencurigai antar pegawai yang disebabkan karena pemberian tugas dan wewenang yang diberikan oleh atasan kurang sesuai dengan kemampuan pegawai dan pimpinan hanya memberikan kewenangan kepada satu dua orang pegawai saja dan yang lainnya tidak difungsikan. Hal inilah yang menyebabkan terhambatnya komunikasi yang ada pada Badan Pemberdayaan Masyarakat Kampung Kabupaten Jayawijaya.

Komunikasi dapat berlangsung dengan beberapa cara yakni secara vertikal dari atas ke bawah maupun dari bawah ke atas dan secara horizontal. Cara-cara komunikasi ini akan sangat mempengaruhi kinerja pegawai, karena sangat tergantung pada mekanisme komunikasi itu sendiri, di mana pada Badan Pemberdayaan Masyarakat Kampung Kabupaten Jayawijaya lebih banyak menggunakan komunikasi verbal yakni komunikasi yang menggunakan simbolsimbol atau kata-kata, baik secara lisan maupun tulisan.

Kemampuan menggunakan komunikasi verbal secara efektif sangat penting bagi pegawai karena memungkinkan pengidentifikasian tujuan, pengembangan strategi dan tingkah laku untuk mencapai tujuan. Pada Badan Pemberdayaan Masyarakat Kampung Kabupaten Jayawijaya terdapat beberapa macam tipe komunikasi verbal, baik secara lisan yakni instruksi, pengarahan, laporan lisan dan pembicaraan maupun secara tulisan berupa surat, memo, petunjuk dan laporan. Agar komunikasi ini berhasil, diperlukan suatu upaya yakni mengetahui karakteristik subyek penerima informasi, obyek informasi dan cara komunikasi (Manullang, 2002).

Hasil pengamatan di lapangan menunjukkan bahwa komunikasi horizontal pada Badan Pemberdayaan Masyarakat Kampung Kabupaten Jayawijaya selama ini masih belum optimal dimana kurang adanya koordinasi antar bidang-bidang dalam melaksanakan tugas, masih ada sebagian pegawai yang mau mendengarkan perintah, instruksi dan pengarahan dari orang tertentu, bukan dari atasan langsungnya. Selain itu, sering terjadi, pegawai sudah menerima instruksi dari kepala badan namun mendapatkan instruksi yang berbeda dari kepala bagian sehingga waktu penyelesaian tugas menjadi terhambat dan kualitas hasil pekerjaan menurun sehingga kinerja organisasi terhambat.

Dengan demikian, dalam artikel ini penulis ingin menganalisa dan mengetahui pengaruh komunikasi horizontal terhadap kinerja pegawai pada badan pemberdayaan masyarakat kampung (BPMK) kabupaten jayawijaya. Adapun permasalahan pokok yang akan dingkat dalam penelitian ini adalah mengenai; Adakah Pengaruh Komunikasi Horizontal Terhadap Kinerja Pegawai pada Kantor Badan Pemberdayaan Masyarakat Kampung (BPMK) Kabupaten Jayawijaya.

\section{Metode Penelitian}

Penelitian ini menggunakan metode penelitian kuantitatif, teknik sampling yang digunakan yakni sampel jenuh. Untuk menguji instrument penelitian, peneliti menggunakan rumus validitas yakni product moment dan rumus reliabilitas yakni alpha cronbach. Teknis analisis data penulis menggunakan rumus korelasi dan regresi. Penelitian dilaksanakan di Kantor Badan Pemberdayaan Masyarakat Kampung di Kabupaten Jayawijaya, Papua.

\section{Hasil dan Pembahasan}

Komunikasi horizontal adalah per- 
Tersedia Online di http://journal.unismuh.ac.id/index.php/otoritas

Otoritas : Jurnal Ilmu Pemerintahan, 7 (1), April 2017, 40

tukaran pesan di antara orang-orang yang sama tingkatan otoritasnya dalam organisasi. Pesan yang mengalir menurut fungsi dalam organisasi diarahkan secara horizontal. Pesan ini biasanya berhubungan dengan tugas-tugas atau tujuan-tujuan kemanusiaan seperti koordinasi, pemecahan masalah, penyelesaian konflik dan saling memberikan informasi (Muhammad, 2007).

Adapun hasil penelitian yang dilakukan di Kantor Badan Pemberdayaan Masyarakat Kampung Kabupaten Jayawijaya disajikan dalam beberapa pengujian dan digambarkan dalam tabel.

Pengujian yang pertama dengan uji validitas instrumen hasil analisis validitas dengan menggunakan program SPSS for windows versi 16 . Dari hasil validitas diperoleh nilai korelasi produk momen masing-masing item pertanyaan pada masing-masing variabel yang disajikan dengan keterangan valid pada tabel 1 dan 2.

Selanjutnya dengan melakukan uji reliabilitas instrumen. Reliabilitas adalah indeks yang menunjukkan sejauh mana suatu relatif konsisten apabila penguku- ran diulangi dua kali atau lebih (Supardi (2005). Pengujian reliabilitas setiap variabel dilakukan dengan Cronbach Alpha Coeficient menggunakan bantuan software SPSS 16.00. Data yang diperoleh akan dapat dikatakan reliable apabila nilai Cronbach's Alpha lebih besar atau sama dengan 0,6. Berdasarkan dengan hasil analisis diperoleh nilai Cronbach's Alpha sebagaimana terpampang pada tabel 3 dan masing-masing variabel lebih dari 0,60 sehingga variabel dikatakan reliabel.

Setelah melakukan dua pengujian sebelumnya, maka dilanjutkan dengan melakukan uji t dan analisis regresi. Untuk menguji pengaruh komunikasi horizontal terhadap kinerja pegawai maka menggunakan rumus $\mathrm{H}_{0}: \beta=0$ untuk Komunikasi horizontal tidak memiliki pengaruh signifikan terhadap kinerja pegawai dan HO : $\beta \neq 0$ untuk Komunikasi horizontal memiliki pengaruh signifikan terhadap kinerja pegawai.

Hasil perhitungan pada tabel 4 diperoleh statistik t sebesar 3,429. Nilai tersebut jika dibandingkan dengan $t$ tabel sebesar 1,703 maka lebih besar sehingga $\mathrm{H} 1$ diterima dan disimpulkan terdapat

Tabel 1. Uji Validitas Variabel Komunikasi Horizontal (Hasil Pengolahan Data, 2016)

\begin{tabular}{cccc}
\hline $\begin{array}{c}\text { Butir } \\
\text { Pertanyaan }\end{array}$ & r hitung & r kritis & Keterangan \\
\hline 1 & 0,493 & 0,381 & Valid \\
2 & 0,546 & 0,381 & Valid \\
3 & 0,456 & 0,381 & Valid \\
4 & 0,651 & 0,381 & Valid \\
5 & 0,664 & 0,381 & Valid \\
6 & 0,417 & 0,381 & Valid \\
7 & 0,660 & 0,381 & Valid \\
8 & 0,656 & 0,381 & Valid \\
9 & 0,529 & 0,381 & Valid \\
10 & 0,527 & 0,381 & Valid \\
11 & 0,474 & 0,381 & Valid \\
12 & 0,508 & 0,381 & Valid \\
13 & 0,590 & 0,381 & Valid \\
14 & 0,505 & 0,381 & Valid \\
15 & 0,45 & 0,381 & Valid \\
\hline
\end{tabular}

Copyright (C) 2017, Otoritas : Jurnal Ilmu Pemerintahan, p-ISSN: 2088-3706, e-ISSN: 2502-9320 
Tersedia Online di http://journal.unismuh.ac.id/index.php/otoritas

Otoritas : Jurnal Ilmu Pemerintahan, 7 (1), April 2017, 41

Tabel 2. Uji Validitas Variabel Kinerja Pegawai (Hasil Pengolahan Data, 2016)

\begin{tabular}{cccc}
\hline $\begin{array}{c}\text { Butir } \\
\text { Pertanyaan }\end{array}$ & r hitung & r kritis & Keterangan \\
\hline 1 & 0,606 & 0,381 & Valid \\
2 & 0,546 & 0,381 & Valid \\
3 & 0,860 & 0,381 & Valid \\
4 & 0,503 & 0,381 & Valid \\
5 & 0,596 & 0,381 & Valid \\
6 & 0,566 & 0,381 & Valid \\
7 & 0,544 & 0,381 & Valid \\
8 & 0,558 & 0,381 & Valid \\
9 & 0,676 & 0,381 & Valid \\
10 & 0,658 & 0,381 & Valid \\
11 & 0,611 & 0,381 & Valid \\
12 & 0,411 & 0,381 & Valid \\
13 & 0,644 & 0,381 & Valid \\
14 & 0,631 & 0,381 & Valid \\
15 & 0,440 & 0,381 & Valid \\
\hline
\end{tabular}

Tabel 3. Hasil Uji Reliabilitas (Hasil Pengolahan Data, 2016)

\begin{tabular}{lcc}
\hline \multicolumn{1}{c}{ Variabel Penelitian } & Cronbach Alpha & Keterangan \\
\hline Komunikasi Horizontal $(\mathrm{X})$ & 0,759 & Reliabel \\
Kinerja Pegawai $(\mathrm{Y})$ & 0,742 & Reliabel \\
\hline
\end{tabular}

pengaruh signifikan komunikasi horizontal terhadap kinerja pegawai pada taraf $95 \%$.

Sedangkan hasil dari analisis regresi menghasilkan parameter statistik yang dirangkum pada tabel 4. Dari parameter statistik yang dihasilkan diperoleh model persamaan regresi yaitu $\mathrm{Y}^{\prime}=9,115+$ 0,795X. Berdasarkan persamaan tersebut, dapat dijelaskan bahwa komunikasi horizontal sebesar 9,115 bila kinerja pegawai $=0$, dan komunikasi horizontal akan meningkat sebesar 0,795 satuan bila kinerja pegawai dinaikan sebesar satu satuan, sebaliknya akan menurun bila kinerja pegawai diturunkan sebesar satu satuan.

Selain itu penulis juga melakukan deskripsi variabel penelitian melalui analisis deskriptif dan disajikan pada tabel 5. Lalu berikutnya dengan melakukan koefisien determinasi yang dimana berguna untuk mengetahui besarnya kontribusi variabel $\mathrm{X}$ terhadap perubahan yang terjadi pada variabel $Y$ yang tergambarkan pada tabel 6, dimana koefisien determinasi sebesar 0,320 atau 32,0\%, artinya bahwa kontribusi komunikasi horizontal terhadap pelaporan kinerja pegawai sebesar 32,0\%.

Dari hasil pengujian ini, terdapat pengaruh signifikan komunikasi horizontal terhadap kinerja pegawai.Untuk mengungkapkan aspek yang akan diteliti maka diperlukan alat ukur yang valid dan reliabel, sehingga kesimpulan dari hasil 
Tersedia Online di http://journal.unismuh.ac.id/index.php/otoritas

Otoritas : Jurnal Ilmu Pemerintahan, 7 (1), April 2017, 42

Tabel 4. Hasil Analisis Regresi Linear (Hasil Pengolahan Data, 2016)

\begin{tabular}{|c|c|c|c|c|c|c|c|}
\hline \multicolumn{3}{|c|}{ Variabel Penelitian } & $\begin{array}{c}\text { Koefisien } \\
\text { Regresi }\end{array}$ & $\begin{array}{l}\text { Nilai } \\
\text { "t" }\end{array}$ & $\begin{array}{c}\text { Korelasi } \\
\text { Parsial }\end{array}$ & Sig & Ket \\
\hline \multicolumn{3}{|c|}{ Komunikasi Horizontal (X) } & 0.795 & 3.429 & 0.566 & 0.002 & Sig \\
\hline Konstanta & $=$ & 9,115 & & & & & \\
\hline
\end{tabular}

Tabel 5. Tabel Analisis Deskriptif (Hasil Pengolahan Data, 2016)

\begin{tabular}{lccccc}
\hline Variabel & N & Minimum & Maximum & Mean & Std. Deviation \\
\hline Kinerja Pegawai & 27 & 32 & 71 & 44.30 & 6.701 \\
Komunikasi Horizontal & 27 & 36 & 53 & 44.26 & 4.768 \\
Valid N (Listwise) & 27 & & & & \\
\hline
\end{tabular}

Tabel 6. Koefisien Determinasi (Hasil Pengolahan Data, 2016)

\begin{tabular}{ccc}
\hline R Square & Adjusted R Square \\
\hline & .320 & .293 \\
\hline
\end{tabular}

Tabel 7. Interpretasi Koefisien Korelasi (Sugiyono, 2008)

\begin{tabular}{ll}
\hline Interval Koefisien & Tingkat Hubungan \\
\hline $0,00-0,199$ & Sangat rendah \\
$0,20-0,399$ & Rendah \\
$0,40-0,599$ & Sedang \\
$0,60-0,799$ & Kuat \\
$0,80-1,000$ & Sangat kuat \\
\hline
\end{tabular}

penelitian tidak menyimpang dan tidak memberikan gambaran yang jauh berbeda dari keadaan yang sebenarnya. Instrumen yang valid dan reliabel merupakan syarat mutlak untuk mendapatkan hasil penelitian yang valid dan reliabel. Valid berarti instrumen tersebut dapat digunakan untuk mengukur apayang seharusnya diukur, sedangkan reliabel adalah bila instrumen digunakan beberapa kali untuk mengukur obyek yang sama, akan menghasilkan data yang sama.

Penelitian ini ada dua variabel yang dianalisis yaitu komunikasi horizontal dan kinerja pegawai.

Uji validitas dilakukan dengan mengkorelasikan antara skor yang diperoleh pada masing-masing pertanyaan dengan skor total (item-total correlation). Wibowo (2004) menjelaskan bahwa instrumen yang valid adalah alat ukur yang digunakan untuk mendapatkan data yang 
Tersedia Online di http://journal.unismuh.ac.id/index.php/otoritas

Otoritas : Jurnal Ilmu Pemerintahan, 7 (1), April 2017, 43

valid dan dapat digunakan untuk mengukur apa yang hendak diukur. Validitas bertujuan untuk menguji apakah tiap item atau instrument benar-benar mampu mengungkap faktor yang akan diukur atau konsistensi internal tiap item alat ukur dalam mengukur suatu faktor. Metode yang digunakan untuk memberikan penilaian terhadap validitas instrumen adalah korelasi produk moment (moment product correlation). Dikatakan validitas suatu instrument apabila $r$ hitung lebih besar dari $r$ tabel dengan tingkat signifikan sebesar $5 \%$ atau 0.05 (Sugiyono, 2011).

Hasil uji validitas variabel Komunikasi horizontal menunjukkan bahwa semua pertanyaan memiliki nilai $r$ hitung di atas dari nilai $r$ tabel dengan alpha 0.05 (5\%). Dengan demikian, maka nomor item pertanyaan pada variabel Komunikasi horizontal adalah valid dan digunakan sebagai dasar analisa lebih lanjut. Indikator Komunikasi horizontal yang memiliki validitas tertinggi yaitu pada butir pertanyaan nomor 5 dengan nilai 0,66 dan yang terendah pada butir pertanyaan 6 yaitu dengan nilai 0,41.

Sedangkan hasil uji validitas variabel Kinerja pegawai menunjukkan bahwa semua indikator variabel Kinerja pegawai memiliki nilai $r$ hitung di atas dari nilai $r$ tabel dengan alpha 0.05 (5\%) Dengan demikian, maka semua pertanyaan pada variabel laporan Kinerja Pegawai adalah valid. Indikator Kinerja pegawai yang memiliki validitas tertinggi yaitu pada butir pertanyaan nomor 3 dengan nilai 0,85 sedangkan validitas terendah terdapat pada butir pertanyaan 15 yaitu dengan nilai 0,50 .

Setelah dapat ditentukan bahwa kuesioner yang dibuat dalam penelitian ini valid, maka dilanjutkan dengan uji reliabilitas. Uji ini hanya dapat dilakukan pada pertanyaan-pertanyaan yang valid. Kegunaan uji ini adalah untuk mengetahui sejauh mana pengukuran ini dapat memberikan hasil yang relatif tidak berbeda bila dilakukan pengukuran kembali terhadap subyek yang sama.

Uji realibitas dengan mengunakan metode alpha cronbach's, yang diukur berdasarkan skala alpha cronbach's 0 sampai dengan 1. Variabel dikatakan reliabel jika nilai alpha sama dengan atau lebih dari 0,6 (Usman dan Akbar, 2006).

Dari hasil uji reliabilitas variabel Komunikasi horizontal diperoleh nilai sebesar 0,759. Karena nilai alpha lebih dari 0,6 sehingga variabel Komunikasi horizontal dikatakan reliabel. Sedangkan hasil uji reliabilitas variabel Kinerja pegawai diperoleh nilai sebesar 0,742. Karena nilai alpha lebih dari 0,6 sehingga variabel Kinerja pegawai dikatakan reliabel.

Interpretasi korelasi antara Komunikasi horizontal dengan kinerja pegawai penulis menggunakan pendapat Sugiyono (2008) sebagaimana disajikan pada tabel 7.

Berdasarkan hasil perhitungan koefisien korelasi, maka diperoleh nilai sebesar 0,795, sehungga hubungan kedua variabel tersebut masuk dalam kategori kuat $(0,60-0,799)$, ini berarti bahwa semakin tinggi komunikasi horizontal maka kinerja pegawai semakin baik.

Hasil analisa juga menunjukkan bahwa hubungan antara komunikasi horizontal dengan kinerja pegawaibersifat searah/positif. Dan terdapat pengaruh signifikan komunikasi horizontal terhadap kinerja pegawai pada taraf 95\%.

Seperti diketahui bahwa Komunikasi horizontal adalah pertukaran pesan di antara orang-orang yang sama tingkatan otoritasnya dalam organisasi. Pesan yang mengalir menurut fungsi dalam organisasi diarahkan secara horizontal. Pesan ini biasanya berhubungan dengan tugas-tugas atau tujuan-tujuan kemanusiaan seperti koordinasi, pemecahan masalah, penyelesaian konflik dan saling memberikan informasi (Muhammad, 2007 :65).

Demikian pula dikemukakan oleh Hasibuan (2001 :56) bahwa selain komu-

Copyright (C) 2017, Otoritas : Jurnal Ilmu Pemerintahan, p-ISSN: 2088-3706, e-ISSN: 2502-9320 
Tersedia Online di http://journal.unismuh.ac.id/index.php/otoritas

Otoritas : Jurnal Ilmu Pemerintahan, 7 (1), April 2017, 44

nikasi vertikal ke atas dan komunikasi vertikal ke bawah, dalam suatu organisasi terdapat pula komunikasi horizontal yang berlangsung antara orang-orang yang berada pada tingkat yang sama dalam hirarki organisasi, akan tetapi melaksanakan kegiatan yang berbedabeda.

Komunikasi horizontal merupakan aspek yang sangat penting dalam mencapai kinerja pegawai. Oleh karena itu komunikasi horizontal sangat dibutuhkan dalam mencapai keberhasilan dalam pelaksanaan pekerjaan, diperlukan adanya koordinasi, dan kemampuan dalam pemecahan masalah serta adanya pertukaran informasi yang terjadi antara pegawai. Kinerja pegawai yang baik apabila tidak ditunjang oleh komunikasi horizontaldiantara pegawai pada Badan Pemberdayaan Masyarakat Kampung Kabupaten Jayawijaya itu sendiri.

Dari penjelasan di atas, menunjukkan bahwa variabel komunikasi horizontal mampu memberikan kontribusi terhadap kegiatan kinerja pegawai yang dilakukan oleh Badan Pemberdayaan Masyarakat Kampung Kabupaten Jayawijaya.

Sedangkan nilai kontribusi yang diberikan oleh komunikasi horizontal terhadap kinerja pegawai di Kantor Badan Pemberdayaan Masyarakat Kampung Kabupaten Jayawijaya sebesar32,0\%, sedangkan 68,0 \% dipengaruhi oleh faktorfaktor lain.

\section{Kesimpulan}

Berdasarkan hasil analisis data yang telah dilakukan, maka dapat diambil kesimpulan bahwa hasil perhitungan koefisien korelasi diperoleh nilai sebesar 0,795 , dan nilai tersebut masuk dalam kategori kuat $(0,60-0,799)$ sehingga hubungan antara komunikasi horizontal dengan kinerja pegawai badan pemberdayaan masyarakat kampung kab. jayawijaya bersifat searah/positif.

Hasil analisa uji t diperoleh statistik t sebesar 3,429. Nilai tersebut jika dibandingkan dengan $t$ tabel lebih besar sehingga $\mathrm{H} 1$ diterima dan disimpulkan terdapat pengaruh signifikan komunikasi horizontal terhadap kinerja pegawai pada taraf 95\%. Kontribusi komunikasi horizontal terhadap Kinerja pegawai sebesar $32,0 \%$, dan sisanya $68 \%$ di pengaruhi oleh faktor lainnya. Selain perlu dilakukannya peningkatan komunikasi horizontal secara terus menerus guna mencapai kinerja pegawai yang diharapkan, perlunya koordinasi yang baik antara pegawai dalam pelaksanaan tugas di dalam satuan kerjanya, perlu peranan pimpinan dalam menyelesaikan berbagai permasalahan yang berhubungan dengan ugas pokok dan fungsinya, dan perlunya pertukaran informasi yang dilakukan terus menerus dalam pelaksanaan tugas pegawai.

\section{Ucapan Terima Kasih}

Ucapan terima kasih dan doa kami haturkan kepada pihak yang membantu proses penelitian hingga proses publikasi pada Otoritas : Jurnal Ilmu Pemerintahan. Terima kasih secara khusus kami haturkan kepada Badan Pemberdayaan Masyarakat Kampung Kabupaten Jayawijaya dan Civitas Akademika STISIP Amal Ilmiah Yapis Wamena, Kabupaten Jayawijaya.

\section{Daftar Pustaka}

Hasibuan, M. (2001). Manajemen Sumberdaya Manusia. Jakarta: Penerbit PT. Gunung Agung.

Manullang, M. (2002). Manajemen Sumber Daya Manusia. Yogyakarta: BPFE.

Muhammad, A. (2007). Komunikasi Organisasi. Jakarta: Bumi Aksara.

Sedarmayanti, S. (1995). Sumber Daya Manusia dan Produktifitas Kerja. Bandung: Ilham Jaya.

Sriwidodo, U., \& Haryanto, A. B. (2010). 
Tersedia Online di http://journal.unismuh.ac.id/index.php/otoritas

Otoritas : Jurnal Ilmu Pemerintahan, 7 (1), April 2017, 45

Pengaruh Kompetensi, Motivasi, Komunikasi Dan KesejahteraanTerhadap Kinerja Pegawai Dinas Pendidikan. Jurnal Manajemen Sumber Daya Manusia, 4(1), 47-57.

Sugiyono, S. (2008). Metode Penelitian Kuantitatif, Kualitatif dan $R \& D$. Bandung: Alfabeta.

Sugiyono, S. (2011). Metode Penelitian Pendidikan (Pendekatan. Kuantitatif, Kualitatif, dan R\&D). Bandung: Alfabeta.
Supardi, S. (2005). Metodologi Penelitian Ekonomi dan Bisnis. Yogyakarta: UII Press.

Usman, H., \& Akbar, R. P. S. (2006). Pengantar Statistika. Jakarta: Bumi Aksara.

Wibowo, W. (2007). Manajemen Kinerja. Jakarta: PT. Raja Grafindo Persada. 